\title{
Young university students and techno-addiction. The use of social networks in their social-educational context
}

\author{
Sandra Martínez Pérez \\ smartinezperez@grupotecnologiaeducativa.es \\ Universidad de Barcelona, Spain \\ Bárbara Fernández Robles \\ bfernandezrobles@gmail.com \\ Universidad Isabel I, Spain

\section{Julio Barroso Osuna} \\ jbarroso@us.es \\ Universidad de Sevilla, Spain

\section{Carmen Llorente Cejudo} \\ karen@us.es \\ Universidad de Sevilla, Spain
}

\begin{abstract}
The use of Smartphones, Tablets and Social Networks has grown exponentially in recent years as a means of communicating, interacting, sharing and working collaboratively. Increasingly, young people are recognising that they are establishing a greater relationship with technologies for educational and leisure purposes, to meet new people, create new languages and even to become dependent on them. The aim of our study is to know, analyse and determine the degree of addiction of young people from twelve Spanish universities. To do this, we applied an adaptation of the "Social Media Addiction Scale-Student Form" (SMAS-SF, Sahin, 2018) which was answered by 1870 students from seven Autonomous Communities (Andalusia, Asturias, Castile and Leon, Catalonia, Galicia, Murcia and the Basque Country). The results obtained show significant differences between the young people of the different Autonomous Communities; moreover, the students do not perceive themselves as people addicted to technology and social networks.
\end{abstract}

\section{Keywords}

Digital addiction; social networks; young people; training; Higher Education. 


\section{Introduction}

Internet and Social Networks have become part of our lives, especially in adolescents and young people, providing new ways to make friends - partners, to be distracted (leisure), to create new languages, to interact, to exchange information, to share, to communicate and to work collaboratively, among others; based on the flexibility of three key factors: time, space and place. This techno-social disruption has led to a rethinking of the transformations and innovations developed in education, and the role played by teachers and students, as active subjects, in their own teachinglearning processes (Cam \& Isbulan, 2012; Al-Rahmi, Othman \& Musa, 2014; Altuzarra, Gálvez \& González, 2018; Cabero et al., 2020). Different studies point out how technologies contribute to the educational process, making themselves visible as support for learning, teaching aids, facilitators of collaboration, knowledge acquisition, research and training; and as a motor for change in institutions and career paths (Brown, 2012; Dyson, Vickers, Turtle, Cowab \& Tassone, 2015; Lim, Grönlund \& Andersson, 2015; Donelan, 2016; Aldahdouh, Nokelainen \& Korhone, 2020).

These new bonds and ways of relating in virtuality bring with them changes in lifestyles, and can be considered a double-edged sword. On the one hand, being constantly connected to the Internet provides the opportunity to build new knowledge and learning (Froment, García \& Bohórquez, 2017; Krull \& Duart, 2018; Cabero et al., 2020). On the other hand, they can lead to vulnerability factors, develop negative attitudes and consequences (anxiety, lack of control, bad habits, etc.), deteriorate social skills and encourage the abusive use of technologies (Chóliz \& Marco, 2012; Chóliz \& Marcos, 2020; Wegmann, Stodt \& Brand, 2015; Mahdiuon, Salimi \& Raeisy 2020). In addition to the latter, the growing concern with finding tools for diagnosis, self-perception scales of social network addiction have been gaining ground. For the present research, Sahin's "Social Media Addiction Scale Student Form (SMAS-SF)" (2018) was taken, which determines possible addictions of students (12-22 years old) in relation to: virtual tolerance, virtual communication, virtual problem and virtual information.

\section{a. Use of social networks in Education}

Adolescents and young people have seen how through the use of social networks they can communicate, generate debate, express and exchange opinions, concerns, feelings and interests; strengthen their socio-educational potential; and improve interpersonal relations between members of the educational community (Burbules, 2016; García, Tirado \& Hernando, 2018). In the area of education, adolescent students value social networks positively as a motivation for learning, although they point out that their main use is oriented towards leisure (Álvarez de Sotomayor \& Muñoz, 2016). However, it is usually seen that such social networks are perceived and used more for social purposes rather than educational purposes (Roblyer et al., 2010). Therefore, it is important to determine what social media and social media usage purposes students use to make educational content interesting and examine the different contexts in which they are embedded. The students' use of online social networks for learning purposes are gathered under the categories of social interaction, following the shares, interacting with materials, collaboration, doing homework, and getting support. Social networking sites, have the capacity to facilitate online discussions and collaboration among students, and between students and teachers, in addition to providing opportunities for the sharing of ideas, educational content as well as enhancement of communication among stakeholders. This is very important in light of the fact that the current generation of students are digital natives. This compels learning to be socially and digitally driven by ubiquitous technologies (Chaka \& Govender, 2020). Social networking sites are being used extensively by many people and their application to education is long overdue in view of the numerous advantages including learner-centred, collaboration, and active participation among others.

In Higher Education, studies such as Gikas \& Grant (2013), Dzvapatsva, Mitrovic \& Dietrich (2014), Jones (2015), Chawinga \& Zinn (2016) and Zachos, Paraskevopoulou-Kollia \& Anagnostopoulos 
(2018) show that the integration of social networks complement educational practices and teaching-learning processes. The use of them in the classrooms, and outside them, gives way to a temporary flexibility, and generates more interaction between its members compared to more traditional methodologies, motivating the student to their participation, knowledge transfer, co-creation and content management; enhancing their creativity, new styles of communication and expression of the construction of their own identity; promoting the development of critical and flexible thinking; designing new spaces for teaching and learning; and promoting the development of technological competences (Conole \& Alevizo, 2010; Terrell, Richardson \& Hamilton, 2011; Menkhoff, Chay, Bengtsson, Woodard \& Gan, 2014; De Wever, Hämäläinen, Voet \& Gielen, 2015; Froment, García \& Bohórquez, 2017).

In contradiction, the integration of networks in education presents a series of difficulties or limitations: risks of privacy and digital identity; lack of a culture of collaboration and teamwork; distraction and lack of attention; waste of time; negative attitude towards their use; social isolation; reduction of cognitive development; and dependence and even addiction (Camacho, 2010; VázquezMartínez \& Cabero, 2015; Chunga, 2016; Durak, 2017).

\section{b. Techno-addiction: the use of social networks}

Different studies show how adolescents and young people are unable to be and function without their phones, as they tend to express themselves more through the virtual environment than through presence and their real world. This flow of "new" possibilities, for this group of the population, on the one hand has brought new habits and changes in behaviour: isolation and neglect of relationships, physical and academic activities; emotional irritability, alterations in moods; problems in decision making, concentration; and even difficulties in the development of memory (Dong, Lin, Zhou \& Lu, 2012; Gómez, 2014; Rücker, Akre, Berchtold \& Suris, 2015; Fundación Mapfre, 2017). And on the other hand, it offers the opportunity to: interact socially, communicate simultaneously with several people and groups, generate new friendships, break and eliminate relationships or contacts, escape from reality, feel "free", entertain oneself, among others (Musial \& Kazienko, 2013; Dirik, 2016; Peña, Rueda \& Pegalajar, 2018).

The speedy access to information, the opportunities offered by technologies, being connected most of the time, knowing what is going on in social networks, and the excessive use of smart phones have made people, especially young people, feel and are continuously "hooked" on the Internet, bringing with it one of the most notable effects: techno-addiction or addiction to technologies, in our case to social networks (Lee, 2006; Aktas \& Yllmaz, 2017; Arnavut, Nuri \& Direktör, 2018; Müller et al., 2016; Gordo, García, De Rivera \& Díaz, 2018, Hinojo-Lucena, Aznar-Díaz, CáceresReche, Trujillo-Torres \& Romero-Rodríguez, 2020). For Griffiths (1995), technological addictions are marked by a series of addictive behaviours (gambling, physical exercise, video games, among others); and he defined them as "non-chemical (behavioural) addictions that involve the interaction between people and machines" (p. 15). Later years, techno-addiction is understood as "the excessive inclination towards the use of technologies, which limit human freedom due to the great dependence they cause" (Red.es, 2015).

In order to be able to indicate that a person shows addictive behaviours towards the Internet, it is important to differentiate between appropriate and inappropriate use of the Internet, which is classified into three categories: use, abuse and addiction (Fundación Mapfre, 2017). It is understood by: a) use, the type of relationship established with the technology without quantity, time, frequency and mode of use giving rise to negative consequences; b) abuse, inappropriate use between technology, time, frequency or type of use manifesting negative consequences for the person and his or her own environment; and c) addiction, the appearance of three symptoms: 1) tolerance (increasing the time of use of technology); 2) abstinence (discomfort when not using technology); and 3) dependence (the person needs to increase the use of technology, because if he does not do so he feels bad). Thus, the main addictions to technologies, according to the study by 
Chóliz and Marcos (2020), would be Internet, mobile phones, social networks and video games. The reasons for linking technologies to addictions will depend on structural characteristics and conditions of use. A greater use of technologies increases the possible symptoms of addictive disorders similar to substance use (Baggio et al, 2018), presenting behaviours such as a) tolerance (need to be connected for a longer period of time); b) abstinence (feeling of discomfort when not connected); c) increasing use of the medium; d) desire to use the internet continuously (difficulty in disconnecting), which leads to a greater investment of time in internet-related activities; e) neglect or abandonment of other activities (sole and exclusive use of the internet); and f) problems of selfesteem, self-control and identity development (Chóliz \& Marco, 2012; Cabero, Pérez-Díez \& Valencia-Ortiz, 2020; Hinojo-Lucena et al., 2020).

The scenario that has been drawn up leads us to reflect on the socio-educational use of social networks in adolescents and young people. And to find out about the degree of addiction that university students have to them. Some of them are aware of their addiction and others, however, are not aware of its existence.

\section{Method}

\section{a. Research aims}

The research objectives being pursued are as follows:

- $\quad$ To find out the degree of addiction that young people at different Spanish universities have towards social networks, according to the SMAS-SF scale (Sahin, 2018).

- To analyse the degree of addiction that young Spanish university students have towards social networks.

- To analyse whether the gender of young Spanish university students influences the addiction shown towards social networks, according to the SMAS-SF scale (Sahin, 2018).

\section{b. Participants}

The sample was made up of 1870 university students from seven Spanish Autonomous Communities (Andalusia, Asturias, Castile and Leon, Catalonia, Galicia, Murcia and the Basque Country). Twelve universities participated in the study (table 1$) .33 \%(f=614)$ were male and $67 \%(f=1256)$ were female.

\begin{tabular}{|c|c|c|c|c|}
\hline & Universities & Autonomous Community & $\mathrm{F}$ & $\%$ \\
\hline UGR & University of Granada & Andalusia & 103 & 5,51 \\
\hline UMA & University of Malaga & Andalusia & 158 & 8,45 \\
\hline US & University of Seville & Andalusia & 182 & 9,73 \\
\hline UNIOVI & University of Oviedo & Asturias & 77 & 4,12 \\
\hline UVA & University of Valladolid & Castile and Leon & 79 & 4,22 \\
\hline UI1 & University of Isabel I & Castile and Leon & 42 & 2,25 \\
\hline UAB & Autonomous University of Barcelona & Catalonia & 280 & 14,97 \\
\hline UB & University of Barcelona & Catalonia & 331 & 17,70 \\
\hline URL & University of Ramon Llull & Catalonia & 110 & 5,88 \\
\hline
\end{tabular}




\begin{tabular}{|l|l|l|l|l|}
\hline USC & University of Santiago de Compostela & Galicia & 284 & 15,19 \\
\hline UM & University of Murcia & Murcia & 106 & 5,67 \\
\hline UPV & University of the Basque Country & Basque Country & 118 & 6,31 \\
\hline TOTAL & 12 & 7 & 1870 & 100 \\
\hline
\end{tabular}

Table 1. Research sample

The sampling was of the non-probability type, also called convenience or causal (Alaminos, 2006; Kohler, Kreuter \& Stuart, 2019), which is determined by the ease of access that the researcher has to the subjects that make up the population.

\section{b. Instruments}

The instrument, developed by Sahin (2018) called "Social Media Addiction Scale-Student Form", validated and adapted, consisted of 29 items with Likert-type scale construction and five response options ranging from "totally agree" to "totally disagree". The version of the questionnaire used was adapted to the Spanish context and validated through the different phases explained below. For the construction and validation of the questionnaire we based ourselves on a study carried out by Valencia and Castaño (2019), who proceeded to: a) the exploratory factor analysis, previously calculating the Kaiser-Meyer-Olkin measure of sample adequacy and the Bartlett sphericity test (Cerny and Kaiser, 1977); b) the successive reduction of items until perfect factorization (Seçer, 2013), adopting for the elimination of the items either the little effect of the item load on the factor or its location in two factors; (c) confirmatory factor analysis to test the structure of the factor model obtained; and (d) the development of a confirmatory factor analysis, for the definitive comparison of the model, and the application of different adaptation indices for contracting the adaptation of the model (Kline, 2005).

To this end, we followed the following phases: 1) the review of the literature; 2) the development of a Likert-type instrument; 3) the validation through expert judgement; 4) the analysis of its reliability and validity, obtaining the internal consistency of the scale, Cronbach's alpha and "composite reliability" were calculated using Jöreskog's rho (Cho, 2016); and 5) significant results in a pilot study carried out by Valencia-Ortiz and Castaño (2019).

The survey was administered via the Internet to facilitate the collection of information. And, the data were collected during the 2019-20 academic year.

\section{Results}

The statistical analyzes were carried out using the statistical package SPSS 24.

According to the study carried out by Valencia-Ortiz and Castaño (2019) and the adaptation by means of the factorial analysis they performed, an item was eliminated (24: "I use social networks even when I am on the street to be instantly informed about events") because two factors were loaded simultaneously. In this way, the scale remained at 28 items grouped into four factors: problems, satisfaction, obsession with being informed and the need to be connected (table 2). 


\begin{tabular}{|c|c|}
\hline Factors & Items \\
\hline Need to be connected & $\begin{array}{l}\text { 1. I am eager to go on social media. } \\
\text { 2. I look for internet connectivity everywhere so as to go on soci- } \\
\text { al media. } \\
\text { 3. Going on social media is the first thing I do when I wake up in } \\
\text { the morning. } \\
\text { 12. I want to spend time on social media when I am alone. } \\
\text { 14. Social media activities lay hold on my everyday life. } \\
\text { 18. Being on social media excites me. }\end{array}$ \\
\hline Satisfaction & $\begin{array}{l}\text { 4. I see social media as an escape from the real world. } \\
\text { 5. A life without social media becomes meaningless for me. } \\
\text { 6. I prefer to use social media even there are somebody around } \\
\text { me. } \\
\text { 7. I prefer the friendships on social media to the friendships in } \\
\text { the real life. } \\
\text { 8. I express myself better to the people with whom I get in con- } \\
\text { tact on social media. } \\
\text { 9. I am as I want to seem on social media. } \\
\text { 10. I usually prefer to communicate with people via social media. } \\
\text { 11. Even my family frown upon, I cannot give up using social } \\
\text { media. } \\
\text { 13. I prefer virtual communication on social media to going out. }\end{array}$ \\
\hline Problems & $\begin{array}{l}\text { 15. I pass over my homework because I spend much time on so- } \\
\text { cial media. } \\
\text { 16. I feel bad if I am obliged to decrease the time I spend on so- } \\
\text { cial media. } \\
\text { 17. I feel unhappy when I am not on social media. } \\
\text { 19. I use social media so frequently that I fall afoul of my family. } \\
21 \text {. I do not even notice that I am hungry and thirsty when I am } \\
\text { on social. } \\
22 \text {. I notice that my productivity has diminished due to social } \\
\text { media. } \\
\text { 23. I have physical problems because of social media use. }\end{array}$ \\
\hline
\end{tabular}




\begin{tabular}{|l|l|}
\hline & $\begin{array}{l}\text { 20. The mysterious world of social media always captivates me. } \\
\text { 25. I like using social media to keep informed about what hap- } \\
\text { pens. } \\
\text { 26. I surf on social media to keep informed about what social } \\
\text { media groups share. } \\
\text { Obsession with being } \\
\text { informed }\end{array}$ \\
$\begin{array}{l}\text { 27. I spend more time on social media to see some special an- } \\
\text { nouncements (e.g. birthdays). } \\
\text { 28. Keeping informed about the things related to my courses } \\
\text { (e.g. homework, activities) makes me always stay on social me- } \\
\text { dia. } \\
\text { 29. I am always active on social media to be instantly informed } \\
\text { about what my kith and kin share. }\end{array}$ \\
\hline
\end{tabular}

Table 2. Identification of factors with their corresponding ítems.

The internal consistency index finally obtained, both for the overall scale and for the four factors identified, is presented in table 3 . The values obtained are considered high and acceptable or very high according to O'Dwyer and Bernauer (2014).

\begin{tabular}{|l|l|}
\hline Factors & \multicolumn{1}{|c|}{ Alfa } \\
\hline Global & .913 \\
\hline Problems & .806 \\
\hline Satisfaction & .796 \\
\hline Obsession with being informed & .789 \\
\hline Need to be connected & .731 \\
\hline
\end{tabular}

Table 3. Cronbach's alpha for the total of the instrument and factors

The results obtained in the administration of the scale (table 4) offer the average scores and the standard deviations reached for each of the items, and the data for each of the factors (problems $m=1,99, S D=, 667$; satisfaction $m=1,99, S D=, 675$; obsession $m=2,94, S D=, 707$; and need $\mathrm{m}=2,94, \mathrm{SD}=, 854$ ) and their total $\mathrm{m}=2,46, \mathrm{SD}=, 580$.

\begin{tabular}{|l|l|l|}
\hline & M & SD \\
\hline 1. I am eager to go on social media. & 2,88 & 1,012 \\
\hline 2. I look for internet connectivity everywhere so as to go on social media. & 2,86 & 1,152 \\
\hline $\begin{array}{l}\text { 3. Going on social media is the first thing I do when I wake up in the } \\
\text { morning. }\end{array}$ & 3,03 & 1,271 \\
\hline 4. I see social media as an escape from the real world. & 2,25 & 1,115 \\
\hline 5. A life without social media becomes meaningless for me. & 1,82 &, 951 \\
\hline 6. I prefer to use social media even there are somebody around me. & 1,98 &, 934 \\
\hline $\begin{array}{l}\text { 7. I prefer the friendships on social media to the friendships in the real } \\
\text { life. }\end{array}$ & 1,55 &, 841 \\
\hline
\end{tabular}




\begin{tabular}{|c|c|c|}
\hline $\begin{array}{l}\text { 8. I express myself better to the people with whom I get in contact on } \\
\text { social media. }\end{array}$ & 2,25 & 1,128 \\
\hline 9. I am as I want to seem on social media. & 2,06 & 1,102 \\
\hline 10. I usually prefer to communicate with people via social media. & 2,17 & 1,053 \\
\hline 11. Even my family frown upon, I cannot give up using social media. & 2,13 & 1,115 \\
\hline 12. I want to spend time on social media when I am alone. & 3,00 & 1,156 \\
\hline 13. I prefer virtual communication on social media to going out. & 2,14 & 1,044 \\
\hline 14. Social media activities lay hold on my everyday life. & 2,56 & 1,070 \\
\hline $\begin{array}{l}\text { 15. I pass over my homework because I spend much time on social me- } \\
\text { dia. }\end{array}$ & 2,22 & 1,107 \\
\hline $\begin{array}{l}\text { 16. I feel bad if I am obliged to decrease the time I spend on social me- } \\
\text { dia. }\end{array}$ & 1,80 & ,951 \\
\hline 17. I feel unhappy when I am not on social media. & 2,71 & 1,020 \\
\hline 18. Being on social media excites me. & 1,60 &, 811 \\
\hline 19. I use social media so frequently that I fall afoul of my family. & 2,38 & 1,047 \\
\hline 20. The mysterious world of social media always captivates me. & 1,53 & ,844 \\
\hline $\begin{array}{l}\text { 21. I do not even notice that I am hungry and thirsty when I am on soci- } \\
\text { al. }\end{array}$ & 2,57 & 1,249 \\
\hline 22. I notice that my productivity has diminished due to social media. & 1,72 & ,929 \\
\hline 23. I have physical problems because of social media use. & 2,28 & 1,154 \\
\hline 25. I like using social media to keep informed about what happens. & 3,66 & 1,041 \\
\hline $\begin{array}{l}\text { 26. I surf on social media to keep informed about what social media } \\
\text { groups share. }\end{array}$ & 3,26 & 1,066 \\
\hline $\begin{array}{l}\text { 27. I spend more time on social media to see some special announce- } \\
\text { ments (e.g. birthdays). }\end{array}$ & 2,66 & 1,107 \\
\hline $\begin{array}{l}\text { 28. Keeping informed about the things related to my courses (e.g. ho- } \\
\text { mework, activities) makes me always stay on social media. }\end{array}$ & 3,12 & 1,081 \\
\hline $\begin{array}{l}\text { 29. I am always active on social media to be instantly informed about } \\
\text { what my kith and kin share. }\end{array}$ & 2,76 & 1,128 \\
\hline Problems & 1,99 &, 667 \\
\hline Satisfaction & 1,99 &, 675 \\
\hline Obsession with being informed & 2,94 & ,707 \\
\hline Need to be connected & 2,94 &, 854 \\
\hline Total & 2,46 & ,580 \\
\hline
\end{tabular}

Table 4. Mean and standard deviations of items, factors and overall scale depending on the respondents. 
As can be observed, the items with the highest scores obtained are, on the one hand: 1 ("I am eager to go on social media", $m=2,88$ ), 2 ("I look for internet connectivity everywhere so as to go on social media", $m=2,86$ ), 3 ("going on social media is the first thing I do when I wake up in the morning", $m=3,03$ ) and 12 ("I want to spend time on social media when I am alone", $m=3,00$ ) belonging to the need to be connected factor $(m=2,94)$; and on the other: 25 ("I like using social media to keep informed about what happens", $m=3,66$ ), 26 ("I surf on social media to keep informed about what social media groups share", $m=3,26$ ) y 28 ("Keeping informed about the things related to my courses (e.g. homework, activities) makes me always stay on social media", $m=3,12)$ of the obsession with being informed $(m=2,94)$. Although the averages $(m=2.94)$ are the same for both factors, the difference is found in the items of obsession, being higher in relation to the need factor. The factors satisfaction and problems, both with a mean $=1.99$, are below the other two factors indicated.

Concerning the hypothesis of whether gender had an impact on the possible degree of addiction to ORS, we formulate the following hypotheses:

- $\quad$ Null hypothesis $\mathrm{HO}$ ): There are no significant differences between young people according to gender in the answers given to the adaptation of the questionnaire "Social Media Addiction Scale-Student Form" (SMAS-SF) (Sahin, 2018), with an alpha risk of error of 0.05.

- $\quad$ Alternative hypothesis (H1): If there are significant gender differences in the answers given to the adaptation of the questionnaire "Social Media Addiction Scale-Student Form" (SMASSF) (Sahin, 2018), with an alpha risk of error of 0.05 .

Table 5 provides the size of each group, the average range resulting from the assignment of ranges to each group and the sum of those ranges.

\begin{tabular}{|c|c|c|c|c|}
\hline & Gender & $\mathrm{N}$ & Average range & Sum of ranges \\
\hline \multirow{3}{*}{ Problems } & Female & 1256 & 906,49 & 1138555,50 \\
\hline & Male & 614 & 994,84 & 610829,50 \\
\hline & Total & 1870 & & \\
\hline \multirow{3}{*}{ Satisfaction } & Female & 1256 & 887,19 & 1114310,50 \\
\hline & Male & 614 & 1034,32 & 635074,50 \\
\hline & Total & 1870 & & \\
\hline \multirow{3}{*}{$\begin{array}{l}\text { Obsession with being } \\
\text { informed }\end{array}$} & Female & 1256 & 946,60 & 1188934,50 \\
\hline & Male & 614 & 912,79 & 560450,50 \\
\hline & Total & 1870 & & \\
\hline \multirow{3}{*}{ Need to be connected } & Female & 1256 & 957,61 & 1202762,00 \\
\hline & Male & 614 & 890,27 & 546623,00 \\
\hline & Total & 1870 & & \\
\hline \multirow{3}{*}{ Total } & Female & 1256 & 920,94 & 1156697,00 \\
\hline & Male & 614 & 965,29 & 592688,00 \\
\hline & Total & 1870 & & \\
\hline
\end{tabular}

Table 5. Ranges by gender 
Table 6 presents the contrast of test statistics taking into account the gender grouping variable, and the four factors: problems $(p)$, satisfaction ( $s)$, obsession with being informed (o) and the need to be connected $(n)$. For this, we have preceded the analysis of Mann-Whitney's U-statistics (total $=367301,000 ; p=349159,500 ; s=324914,500 ; \quad 0=371645,500 ;$ and $\mathrm{n}=357818,000$ ), and Wilcoxon's W-statistics (total $=1156697,000 ; p=1138555,500 ; s=1114310,500 ; \quad 0=560450,500$; and $n=546623,000$ ). The typification of both (total) is value $Z=-1.668$. And the total bilateral critical level (bilateral asymptotic significance) is value Bil=,095. Therefore, we can confirm that the data obtained are significant, we do not reject the different formulas of $\mathrm{HO}$, so we can indicate that there are no significant differences between young people according to gender in the answers given to the adaptation of the questionnaire of the "Social Media Addiction Scale-Student Form" (SMAS$\mathrm{SF})$. There are only differences between men and women in the obsession factor ( $\mathrm{Sig}=, 202)$.

\begin{tabular}{|l|l|l|l|l|l|}
\hline & Problems & Satisfaction & $\begin{array}{c}\text { Obsession } \\
\text { with being } \\
\text { informed }\end{array}$ & $\begin{array}{c}\text { Need to be } \\
\text { connected }\end{array}$ & \multicolumn{1}{|c|}{ Total } \\
\hline Mann-Whitney U & 349159,500 & 324914,500 & 371645,500 & 357818,000 & 367301,000 \\
\hline Wilcoxon W & 1138555,500 & 1114310,500 & 560450,500 & 546623,000 & 1156697,000 \\
\hline Z & $-3,329$ & $-5,547$ & $-1,275$ & $-2,543$ & $-1,668$ \\
\hline Bil. A. Sig. &, 001 &, 000 &, 202 &, 011 &, 095 \\
\hline
\end{tabular}

Table 6. Test statistic contrasta

a. Clustering variable: Gender

\section{Discussion and conclusions}

The abusive use of social networks can sometimes be considered as an addiction problem that can affect health issues (Mora, Dolengevich \& Quintero, 2015). Among these problems we can find social isolation (Echeberúa, 2012), lack of relationship with family members (Fernández-Villa et al., 2015) or the appearance of anxiety as a consequence of its lack of use (Koyuncu, Unsal \& Arslantas, 2014; Kuss \& Griffiths, 2017).

In the present study, we found that the participants show a greater impact on elements related to the need to be connected and informed through social networks ("Need to be connected-2.94" and "Obsession with being informed-2.94") than with Aspects related to problems with them or to the satisfaction received in their use ("problems-1.99" and "satisfaction-1.99"), taking into account that the average value is 2.46. Therefore, we agree with different authors (Griffiths, Kuss \& Demetrovics, 2014; Yu, Wu \& Pesigan, 2016; Berte, Mahamid \& Affouneh, 2019; Whitaker \& Brown, 2020), who affirm that the behaviour maintained by young people and adolescents facing social networks, it cannot be considered an addiction to a behaviour; but rather as an excess and abuse of its use, which on the other hand our data does not confirm; as suggested by the satisfaction and problem factors, the mean score was 1.99. Without forgetting that the mean value obtained for the total scale was 2.46 , which is slightly below the central value of the same, which was located at 2.5.

Participants show a greater use of social networks to stay informed rather than to escape the real world, as shown by the data ("28. Staying informed about things related to my courses makes me always stay on social networks-3.12", and "4. I see networks as an escape from the real world-2.25"). Another element to point out in this line is related to the low results achieved in the 
item that refers to the preference for having friendships in social networks compared to real life ("7. I prefer friendships in social networks than in social networks in real life-1.55"), showing that we are moving away in this sense from a possible social isolation produced by the use of social networks. These results are relevant, since, as reflected by Padilla and Ortega (2017), the use of social networks in excess may have a direct relationship with low self-esteem, lack of social skills and depressive symptoms.

Likewise, the study does not reflect a high impact on the decline in the family relationship as a result of the use of social networks ("19. I use social networks so frequently that I come into conflict with my family-2.38"), data which are in line with those achieved by various authors (Cabero et al., 2020; Valencia \& Castaño, 2019).

Along the same lines, we have not found problems related to the drop in productivity due to the use of social networks ("22. I notice that my productivity has decreased due to social networks-1.72"), these data coincide with those obtained in other studies (Cabero et al., 2020; Marín, Sampedro \& Muñoz, 2015; Valencia \& Castaño, 2019). Therefore, unlike Linne (2015), the students in our study do not show dispersion and distraction when using social networks.

Due to the aforementioned, regarding one of the main objectives of our research, which sought to analyze whether young Spanish university students could be considered addicts to social networks, we have to indicate that there are strong signs that they are not addicted to them. The results coincide with those obtained by Marín, Sampedro and Muñoz (2015), since in their study they found that Spanish university students are not addicted to social networks. Data that are in the direction also of those obtained by Cabero et al. (2020) with young people and adolescents from different Latin American countries, but they do not coincide with those achieved in other studies in which the participants were addicted (Linne, 2015; Pontes, Szabo \& Griffiths, 2015; Berte, Mahamid \& Affouneh, 2017; Whitaker \& Brown, 2020).

However, the results obtained reflect that the use of social networks can cause anxiety to be connected, manifesting itself in the constant search for connection ("2. I look for Internet connectivity everywhere to access social networks-2.86"), in spending more time on social media when alone ("12. I want to spend more time on social media when alone-3.00") and on being the first thing to do in the morning upon waking ("3. Social media is the first thing I do when I wake up in the morning-3.03"). This element must be controlled, since among the alarms that must be observed as dependence on social networks we find the need to be connected for more time, the increase in discomfort due to its lack of use and the difficulty to disconnect (Baggio et al., 2018).

In relation to the hypotheses raised about the existing differences in addiction to social networks according to gender, we found that in general there are no differences, however, if they appear based on the obsession factor. In this sense, we agree with Basteiro, Robles-Fernández, JuarrosBasterretxea and Pedrosa (2016) in the absence of differences in addiction to social networks based on sex in general, but we agree with Cabero et al. (2020) in which there are differences in obsession depending on gender.

The data obtained in the research lead us to reflect on the importance of educating young students in the use of social networks, since according to authors such as Domínguez-Vergara and YbañezCarranza (2016), the greater the ability of self-control, the lower the need to spend more time on social media.

In view of the possible risks that the abusive use of social networks can produce, we consider it necessary that both parents and educators help from the earliest stages to develop skills that can reduce these risks, among which we find: "agreeing hours of use of the internet and computer; promote relationships with other people; encourage team sports activities; stimulate family communication" (Ramón-Cortés, 2010; cited in Echeberúa, 2010, p. 94). In short, it is very important to raise awareness of the impact of their presence on social networks and their digital identity, 
working on essential rules to be able to function in the virtual context (Argente, Vivancos, Alemany \& García Fornes, 2017). Significantly, the study is also linked to the findings obtained by HinojoLucena et al. (2020), where statistically significant differences were found in internet addiction and self-control based on age.

\section{References}

Aktaş, H., \& Yılmaz, N. (2016). Smartphone addiction in terms of the elements of loneliness and shyness of university youth. International Journal of Social Sciences and Education Research, 3(1), 85-100. DOI: 10.24289 /ijsser. 283590

Alaminos, A. (2006). El muestreo en la investigación social. En A. Alaminos \& J.L. Castejón. Elaboración, análisis e interpretación de encuestas, cuestionarios y escalas de opinión (pp. 46-67). Alcoy: Marfil - Universidad de Alicante.

Aldahdouh, T. Z., Nokelainen, P. \& Korhone, Y. (2020). Technology and Social Media Usage in Higher Education: The influence of individual innovativeness. SAGE Open, 10(1), 1-20, doi: https://doi.org/ $10.1177 / 2158244019899441$

Al-Rahmi, W., Othman, M. S., \& Musa, M. A. (2014). The improvement of students' academic performance by using social media through collaborative learning in Malaysian higher education. Asian Social Science, 10(8), 210-221. https://doi.org/10.5539/ass.v10n8p210

Altuzarra, A., Gálvez, C. \& González, A. (2018). Explorando el potencial de los dispositivos electrónicos y de las redes sociales en el proceso enseñanza-aprendizaje de los universitarios. EDUTEC. Revista Electrónica de Tecnología Educativa, 64, 18-40. https://doi.org/10.21556

Álvarez de Sotomayor, I. \& Muñoz, P. C. (2016). Las redes sociales como motivación para el aprendizaje: opinión de los adolescentes. INNOEDUCA. International Journal of Tecnhology and Education Innovatio, 2(1), 20-28. http://dx.doi.org/10.20548/innoeduca.2016.v2i1.1041

Argente, E., Vivancos, E., Alemany, J., García-Fornes, A. (2017). Educando en privacidad en el uso de las redes sociales. Education in the Knowledge Society, 18(2), 107-126. Recuperado de http://www.redalyc.org/ articulo. 0 a? $\mathrm{id}=535554766007$

Arnavut, A., Nuri, C. \& Direktör, C. (2018). Examination of the relationship between phone usage and smartphone addiction based on certain variables. Anales de Psicología, 34(3), 446-450. http://dx.doi.org/ 10.6018/analesps.34.3.321351

Baggio, S., Starcevic, V., Studer, J., Simon, O., Gainsbury, S. M., Gmel, G. \& Billieux, J. (2018). Technology-mediated addictive behaviors constitute a spectrum of related yet distinct conditions: A network perspective. Psychology of Addictive Behaviors, 32(5), 564-572. doi://dx.doi.org/10.1037/adb0000379

Basteiro, J., Robles-Fernández, A., Juarros-Basterretxea, J. \& Pedrosa, I. (2016). Adicción a las redes sociales: creación y validación de un instrumento de medida. RIDPSICLO, 1(3), 7. Recuperado de http://www.ridpsiclo.ull.es/index.php/ridpsiclo/article/view/35/26

Berte, D.Z., Mahamid, F.A. \& Affouneh, S. (2019, November). Internet Addiction and Perceived Self-Efficacy Among University Students. International Journal of Mental Health and Addiction, https://doi.org/ $10.1007 / \mathrm{s} 11469-019-00160-8$

Brown, S. A. (2012). Seeing Web 2.0 in context: A study of academic perceptions. Internet and Higher Education, 15(1), 50-57. https://doi.org/10.1016/j.iheduc.2011.04.003

Burbules, N. C. (2016). How We Use and Are Used by Social Media in Education. Educational Theory, 66(4), 551-565. https://doi.org/10.1111/edth.12188

Cabero, J., Martínez, S., Valencia, R., Leiva, J.P., Orellana, M.L, \& Hervey, L. (2020). La adicción de los estudiantes a las redes sociales on-line: un estudio en el contexto latinoamericano. Revista Complutense de Educación, 31(1), 1-11. https://doi.org/10.5209/rced.61722 
Cabero, J., Pérez-Díez, J. L. \& Valencia-Ortiz, R. (2020). Escala para medir la adicción de estudiantes a las redes sociales. Convergencia. Revista de Ciencias Sociales, 27, 1-29. doi: 10.29101/crcs.v27i83.11834

Çam, E. \& Isbulan, O. (2012). A New Addiction for Teacher Candidates: Social Networks. TOJET: Turkish Online Journal of Educational Technology, 11(3), 14-19.

Camacho, M. (2010). Las redes sociales para enseñar y aprender. In L. Castañeda (Ed.). Aprendizajes con redes sociales: Tejidos educativos para los nuevos entornos (pp.90-104). Sevilla: Editorial MAD.

Cerny, B. A. \& Kaiser, H. F. (1977). A Study Of A Measure Of Sampling Adequacy For Factor-Analytic Correlation Matrices. Multivariate behavioral research, 12(1), 43-47. https://doi.org/10.1207/s15327906mbr1201_3

Chaka, J. G., \& Govender, I. (2020). Implementation of mobile learning using a social network platform: Facebook. Problems of Education in the 21st Century, 78(1), 24-47. https://doi.org/10.33225/pec/20.78.24

Chawinga, W. D., \& Zinn, S. (2016). Use of Web 2.0 by students in the Faculty of Information Science and Communications at Mzuzu University, Malawi. South African Journal of Information Management, 18(1). http://dx.doi.org/10.4102/sajim.v18i1.694

Chawinga, W.D. (2017). Taking social media to a university classroom: teaching and learning using Twitter and blogs. International Journal of Educational Technology in Higher Education, 14, https://doi.org/ $10.1186 / \mathrm{s} 41239-017-0041-6$

Cho, E. (2016). Making Reliability Reliable: A Systematic Approach to Reliability Coefficients. Organizational Research Methods, 19(4), 651-682. https://doi.org/10.1177/1094428116656239

Chóliz, M. \& Marco, C. (2012). Adicción a Internet y redes sociales. Tratamiento psicológico. Madrid: Alianza

Chóliz, M. \& Marcos, M. (2020). Detección temprana y prevención de adicciones tecnológicas en adolescentes. Madrid: Fundación Mapfre - Universidad de Valencia.

Chunga, G. R. (2016). Uso académico de las redes sociales: análisis comparativo entre estudiantes y profesorado de la Universidad Católica Santo Toribio de Mogrovejo [PhD Thesis]. Málaga: Universidad de Málaga.

Conole, G., \& Alevizou, P. (2010). A literature review of the use of Web 2.0 tools in Higher Education. Milton Keynes: The Open University.

De Wever, B., Hämäläinen, R., Voet, M., \& Gielen, M. (2015). A wiki task for first-year university students: The effect of scripting students' collaboration. The Internet and Higher Education, 25, 37-44. https:// doi.org/10.1016/j.iheduc.2014.12.002

Dirik, K. (2016). Examination of the relations between smart phone addiction and self-confidence in adolescents in terms of several variables (Master's Thesis). Istanbul: Istanbul Gelisim University.

Domínguez-Vergara, J.A., \& Ybañez-Carranza, J. (2016). Adicción a las redes sociales y habilidades sociales en estudiantes de una institución educativa privada. Propósitos y Representaciones, 4(2), 181 - 230. Doi: http://dx.doi.org/10.20511/ pyr2016.v4n2.122

Donelan, H. (2016). Social media for professional development and networking opportunities in academia. Journal of Further and Higher Education, 40(5), 706-729. https://doi.org/ $10.1080 / 0309877 X .2015 .1014321$

Durak, G. (2017). Using Social Learning Networks (SLNs) in Higher Education: Edmodo Through the Lenses of Academics. International Review of Research in Open and Distributed Learning, 18(1), 84-109. https://doi.org/10.19173/irrodl.v18i1.2623

Dyson, B., Vickers, K., Turtle, J., Cowan, S. \& Tassone, A. (2015). Evaluating the use of Facebook to increase student engagement and understanding in lecture-based classes. Higher Education, 69(2), 303-313. https://doi.org/10.1007/s10734-014-9776-3

Dzvapatsva, G. P., Mitrovic, Z., \& Dietrich, A. D. (2014). Use of social media platforms for improving academic performance at Further Education and Training Colleges. South African Journal of Information Management, 16(1). Retrieved from https://sajim.co.za/index.php/sajim/article/view/604/757 
Dong, G., Lin. X., Zhou, H. \& Lu, Q. (2014), Cognitive flexibility in internet addicts: fMRI evidence from difficultt-easy and easy-to-difficult switching situations. Addictive Behaviors, 39(3), 677-683. DOI: 10.1016/j.addbeh.2013.11.028

Echeberúa, E. (2012). Factores de riesgo y factores de protección en la adicción a las nuevas tecnologías y redes sociales en jóvenes y adolescentes. Revista Española de Drogodependencia, 37(4), 435-447. Recuperado de https://www.aesed.com/descargas/revistas/v37n4_5.pdf

Echeberúa, E. \& De Corral, P. (2010). Adicción a las nuevas tecnologías y las redes sociales en jóvenes: un nuevo reto. Adicciones, 22 (2), 91-96. Recuperado de https://www.adicciones.es/index.php/adicciones/article/view/196/0

Fernández-Villa, T., Aguacil, J., Almaraz, A., Cancela, J.M., Delgado-Rodríguez, M., García-Martín. M., JiménezMejías, E., Lorca, J., Molina, J.A., Ortiz, R., Valero-Juan, L.F. \& Martín. V. (2015). Uso problemático de internet en estudiantes universitarios: factores asociados y diferencias de género. Adicciones, 27(4), 265-275. https://doi.org/10.20882/adicciones.751

Froment, F., García, A., \& Bohórquez, M. R. (2017). The Use of Social Networks as a Communication Tool between Teachers and Students: A Literature Review. TOJET: The Turkish Online Journal of Educational Technology, 16(4), 126-144

Fundación Mapfre (2017). Tecnoadicciones. Guía para el profesorado.Madrid: Fundación Mapfre.

García, R., Tirado, R., y Hernando, A. (2018). Redes sociales y estudiantes: motivos de uso y gratificaciones. Evidencias para el aprendizaje. Aula Abierta, 47(3), 291-298. https://doi.org/10.17811/ rifie.47.3.2018.291-298

Gikas, J., \& Grant, M. M. (2013). Mobile computing devices in higher education: Student perspectives on learning with cellphones, smartphones and social media. The Internet and Higher Education, 19, 18-26. https://doi.org/10.1016/j.iheduc.2013.06.002

Gómez, M. (2014). Guía para posibles pacientes. En J. Carbonell (Coord.). Adicciones tecnológicas qué son y cómo tratarlas (pp. 133-150). Madrid: Síntesis.

Gordo, A., García, A., De Rivera, J. \& Díaz, C. (2018). Jóvenes en la encrucijada digital. Itinerarios de socialización y desigualdad en los entornos digitales. Madrid: Morata.

Griffiths, M.D. (1995). Technological addictions. Clinical Psychology Forum, 76, 14-19.

Griffiths, M. D., Kuss, D. J. \& Demetrovics, Z. (2014). Social networking addiction: An overview of preliminary findings. In K. P. Rosenberg \& L. Curtis (Eds.) Behavioral Addictions: Criteria, Evidence and Treatment. (pp. 119-141). New York: Elsevier.

Hijono-Lucena, F.J., Aznar-Díaz, I., Cáceres-Reche, M.P., Trujillo-Torres, J.M, \& Romero-Rodríguez, J.M. (2020). Shatering: adicción a internet, autocontrol y fotografías online de menores. Comunicar, 28(64), 97-108. https://doi.org/10.3916/C64-2020-09

Jones, A. (2015). How Twitter saved my literature class: a case study with discussion. In C. Wankel, M. Marovich, K. Miller, \& J. Stanaityte (Eds.). Teaching Arts and Science with the New Social Media (pp. 91-105). Bingley: Emerald Group Publishing.

Kline, R. (2005), Principles and practice of structural equation modeling. New York: The Guilford Press.

Kohler, U., Kreuter, F., \& Stuart, E. A. (2019). Nonprobability sampling and causal analysis. Annual Review of Statistics and its Applications, 6. doi:10.1146/annurevstatistics-030718-104951

Koyuncu, T., Unsal, A. \& Arslantas, D. (2014). Assessment of internet addiction and loneliness in secondary and high school students. Journal Pak Med Assoc, 64(9), 998-1002. Recuperado de https:// pubmed.ncbi.nlm.nih.gov/25823176/

Krull G. \& Duart, J. M. (2018). Meeting the Needs of Digital Learners: Learner Support Patterns and Strategies. In E. Ivala (Ed).Proceedings of the 13th International Conference on e-Learning,ICEL 2018, ( $p$. 212-219). Cape Town, South Africa: Academic Conferences and publishing limited.

Lee, Y.S. (2006). Biological Model and Pharmacotherapy in Internet Addiction. J Korean Medical Association, 49(3), 209-219. https://doi.org/10.5124/jkma.2006.49.3.209 
Lim, N., Grönlund, A. \& Andersson, A. (2015). Cloud computing: The beliefs and perceptions of Swedish school principals. Computers and Education, 84, 90-100. https://doi.org/10.1016/j.compedu.2015.01.009

Mahdiuon, R., Salimi, G. \& Raeisy, L. (2020). Effect of social media on academic engagement and performance: Perspective of graduate students. Education and Infornation Technologies, 25, 2427-2446. https:// doi.org/10.1007/s10639-019-10032-2

Linne, J. (2015). Estudiar en Internet 2.0. Prácticas de Jóvenes universitarios de la ciudad de Buenos Aires. Comunicación y Sociedad, 23, 195-213. Recuperado de https://www.redalyc.org/pdf/ 346/34632784009.pdf

Marín, V., Sampedro, B. E. \& Muñoz, J. M. (2015). ¿Son adictos a las redes sociales los estudiantes universitarios? Revista Complutense de Educación, 26, 233-251. https://revistas.ucm.es/index.php/RCED/article/ view/46659

Menkhoff, T., Chay, Y. W., Bengtsson, M L., Woodard, C. J., \& Gan, B. (2014). Incorporating microblogging ("tweeting") in higher education: lessons learnt in a Knowledge Management Course. Computers in Human Behavior, 51(B), 1295-1302. https://doi.org/10.1016/j.chb.2014.11.063

Mora, F., Dolengevich, H. \& Quintero, J. (2015). Protocolo de tratamiento de las adicciones sin sustancia psicoactiva. Medicine. Programa de Formación Médica Continuada Acreditado, 11(86), 5157-5160.

Müller, K.W., Dreier, M., beutel, M. E., Duven, E., Giralt, S. \& Wölfling, K. (2016). A hidden type of internet addition? Intense and additive use of social networking sites in adolescents. Computers in Human Behavior, 55(A), 172-177. https://doi.org/10.1016/j.chb.2015.09.007

Musiał, K. \& Kazienko, P. (2013), Social Networks on the Internet. World Wide Web, 16(1), 31-72. DOI: $10.1007 / \mathrm{s} 11280-011-0155-\mathrm{z}$

O 'Dwyer, L. \& Bernauerr, J. (2014). Quantitative research for the qualitative researcher. Los Angeles: Sage.

Padilla-Romero, C. \& Ortega-Blas, J. (2017). Adicción a las redes sociales y sintomatología depresiva en universitarios. Casus, 2 (1), 47-53. Recuperado de http://repositorio.ucss.edu.pe/bitstream/handle/UCSS/ 252/Padilla_Ortega_articulo_CASUS_2017.pdf?sequence $=1$ \&isAllowed =y

Peña, M. A., Rueda, E. \& Pegalajar, M. C. (2018). Posibilidades didácticas de las redes sociales en el desarrollo de competencias de Educación Superior: percepciones del alumnado. Píxel-Bit. Revista De Medios $Y$ Educación, (53), 239-252. https://doi.org/10.12795/pixelbit.2018.i53.16

Pontes, H.M., Szabo, A. \& Griffiths, M.D. (2015). The impact of Internet-based specific activities on the perceptions of Internet addiction, quality of life, and excessive usage: A cross-sectional study. Addictive Behaviors Reports, 1, 19-25. doi: https://doi.org/10.1016/j.abrep.2015.03.002

Red.es (2015). Tecnoadicciones. Ministerio Industria, Energia y Turismo. Retrieved from http://repositorio.educainternet.es/scormfiles/25.full

Roblyer, M. D., McDaniel. M., Webb, M., Herman, J. \& Vince W. J, (2010). Findings on Facebook in Higher Education: A comparison of college faculty and student uses and perceptions of social networking sites. Internet and Higher Education 13(3), 134-140.

Rücker, J., Akre, C., Berchtold, A. \& Suris, J.C. (2015). Problematic Internet use is associated with substance use in young adolescents. Acta Paediatrica, 104(5). https://doi.org/10.1111/apa.12971

Sahin, C. (2018), Social Media Addiction Scale-Student Form: The Reliability and Validity Study. TOJET: The Turkish Online Journal of Educational Technology, 17(1), 169-182. Retrieved from http://www.tojet.net/articles/v17i1/17117.pdf

Seçer, İ. (2013), SPSS ve LISREL ile pratik veri analizi ve raporlaştırma. Ankara: Anı Yayıncılık.

Terrell, J., Richardson, J., \& Hamilton, M. (2011). Using Web 2.0 to teach Web 2.0: A case study in aligning teaching, learning and assessment with professional practice. Australasian Journal of Educational Technology, 27(5), 846-862. https://doi.org/10.14742/ajet.935

Valencia-Ortiz, R. \& Castaño, C. (2019). Use and abuse of social media by adolescents: a study in Mexico. Pixel-Bit. Revista de Medios y Educación, 54, 7-28. doi: 10.12795/pixelbit.2019.i54.01 
Vázquez-Martínez, A. I. \& Cabero, J. (2015). Las redes sociales aplicadas a la formación. Revista Complutense de Educación, 26, 253-272. https://doi.org/10.5209/rev_RCED.2015.v26.47078

Wegmann E., Stodt B. \& Brand M. (2015). Addictive use of social networking sites can be explained by the interaction of internet use expectancies, internet literacy, and psychopathological symptoms. Journal of Behavioral Addictions, 4(3), 155-162, doi: 10.1556/2006.4.2015.021

Whitaker, M.D. \& Brown, S. (2020). Is Mobile Addiction a Unique Addiction: Findings from an International Sample of University Students. International Journal of Mental Health and Addiction, 18, 1360-1388. https://doi.org/10.1007/s11469-019-00155-5

Yu, S., Wu, A. \& Pesigan, I. (2016). Cognitive and psychosocial health risk factors of social networking addiction. International Journal of Mental Health and Addiction, 14(4), 550-564. https://doi.org/10.1007/ s11469-015-9612-8

Zachos, G., Paraskevopoulou-Kollia, E. A. \& Anagnostopoulos, I. (2018). Social Media Use in Higher Education: A Review. Education Sciences, 8(4), 194. doi:10.3390/educsci8040194 